\title{
格子状リブを有する CFRP サンドイッチ版の局部座屈に関する研究 LOCAL BUCKLING OF CFRP SANDWICH PANELS WITH LATTICED RIBS
}

\author{
立石 寧 俊*，山田聖志** \\ Yasutoshi TATEISHI and Seishi YAMADA
}

\begin{abstract}
Flat rectangular sandwich-type panels were tested in edgewise compression and under four points bending. The sandwich consisted of CFRP faces with latticed GFRP ribs and a phenol or an urethane foam core. First, local buckling (wrinkling) of the faces occurred in the experiments. The results of the experiments were summarized for buckling stress and buckling wavelength. Second, the local buckling stress for the sandwich panels with latticed ribs were obtained from the general theory of the stationary for the total potential energy. The obtained formulae show that the ribs and the core remarkably resist the local buckling of the face. Consequently the agreements between the theories and the experiments for buckling stress and buckling wavelength are discussed.
\end{abstract}

Keywords: CFRP Sandwich Panel, Local Buckling, Wrinkling, Latticed Ribs, Core CFRP サンドイッチ版、局部座屈、リンクリング、格子状リブ、コア

\section{1. 序論}

CFRP（炭素瀻維強化プラスチック）材料は、比強度、比剛性に優 れ、耐食性にも優れることから、航空機、船舶、自動車などの輸送

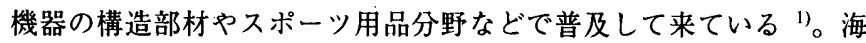
外の土木分野では、軽量化や塩害対策、非磁性化の求められる道路 橋の床版等へFRP デッキを使用した例が見られる ${ }^{2)}$ 。一方、国内の 建築分野では、耐食性に優れた CFRP 製立体トラスを屋内温水プー ルの屋根架構に使用した例 ${ }^{3)}$ p体育館屋根など既存のPCa 版を軽量 な一体成形の CFRP サンドイッチ屋根版に置き換えることで耐震性 を向上させた例 ${ }^{4)}$ などがあり、今後とも建築部材の軽量化やメンテ ナンスフリーの要求とともに増加していくものと考えられる。

FRP デッキの製造には、引抜成形による形材を接着して床版を構 成する方法の他、減圧吸引成形法により大面積のサンドイッチ版を 一体成形する方法 ${ }^{5)}$ がある。本研究では後者の方法で製造されたサ ンドイッチ版を取り扱う。

サンドイッチ版が圧縮荷重を受ける場合、版全体が単一波形でた わむオイラー座屈や、コア材の剈性が表面材と比較して極端に小さ い場合には表面材が座屈する局部座屈（リンクリング）などの現象 を生じることが知られている。また、曲げ荷重を受ける場合には、 表面材とコア材の滑りや剥離、或いは圧縮側表面材の局部座屈など
の現象が生じる場合がある。表面材の局部座屈は表面材とコア材の 剥離など重大な破壊様式の原因となる場合もあり、局部座屈荷重を 推定しておくことは設計上重要と言える ${ }^{4), 6,7) 。 ~}$

サンドイッチ版の局部座屈をモデル化する場合、表面材とコア材 の関係を弾性床上の梁としてとらえ、二次元的に取り扱う方法があ る。Hoff ${ }^{8)}$ らは、プラスチック積層紙の表面板とセルラーセルロー スコア材の接着接合によるサンドイッチ版について、圧縮試験を行 い、座屈モードに、サンドイッチ版の中立軸に対して、Symmetric と Skewの 2 つのタイ゚があることを観察した。それぞれの座屈モ ードに対し、表面材及びコア材のひずみエネルギーと仕事の関係か ら座屈応力式を導き出した。彼らは、表面材の座屈変形がコア材の 厚さ方向に影響する範囲、及び、座屈荷重と座屈波長の関係を明ら かにした。Yusuff ${ }^{91}$ は、コア材を横方向等価ばねで表わし、コア材が 薄く対称な座屈モードを示す場合と、コア材が厚い場合に分け、弾 性床上の梁の基礎方程式から、それぞれの場合についての座屈応力 式を導き出した。これらの論文では 2 次元的な取り扱いをしている ため、表面材にリブなど絴補強材が存在する場合の座屈補剛効果に ついては考慮していない。一方、三次元的な取り扱い方として、原 $\square^{10)}$ は弾性床上の矩形平板の変位問題を Levy 法で解き、座屈問題 への応用を述べているが、矩形平板の座屈変形が、弾性床の深さ方
* 清水建設侏技術研究所 研究員 ·工修

** 豊橋技術科学大学建設工学系 助教授・工博
Research Engineer, Institute of Technology, Shimizu Corporation, M. Eng. Assoc. Prof., Dept. of Architecture and Civil Engineering, Toyohashi University of Technology, Dr. Eng. 
向に影響する範囲や、座屈荷重に与える影響については考察してい ない。

著者らは、減圧吸引成形法で製造された格子状リブを有するCFRP 表面材とフェノール発泡体コア材からなるサンドイッチ版について、 構造実験を基に、耐震改修用屋根版を開発·実用化してきたが4),11)、 本研究では、フェノール発泡体コア材よりも、更に弾性係数が低い ウレタン発泡体コア材を使用した場合について、圧縮及び曲げ実験 による表面材の局部座屈についての実験結果を報告する。過去に実 施したフェノール発泡体コア材を使用した場合の実験結果と併せ、 座屈応力及び座屈半波長についてまとめる。また、格子状りブを有 するサンドイッチ版の局部座屈応力を、Hoff, Yusuffらの方法を3次 元に拡張し、Total Potential Energyの停留原理を用いて、陽な形の式 として求める。得られた局部座屈応力式を用いて、座屈半波長、コ ア材の厚さと弾性係数、稼リブの間隔が局部座屈応力に与える影響 を考察する。さらに、実験結果と比較することで、本式の有用性を 明らかにする。

\section{CFRP サンドイッチ版の基本構成と材料定数}

CFRPサンドイッチ版は、図にに示す様に表面材、コア、リブで構 成される。表面材の材料は、カーボン䋐維とガラス瀻維で強化した プラスチックス（以下、表面材 1)、又は、ガラス結維のみの強化プ ラスチックス (以下、表面材 2 )、リブの材料は、ガラス繊維強化プ ラスチックス、コアの材料は、ウレタン樹脂発泡体、又は、フェノ 一ル樹脂発泡体である。表面材、コア、リブは、減圧吸引成形法に よって、フェノール樹脂含浸後、オートクレーブによる加熱処理で 一体化される。表1に、本研究で使用したサンドイッチ版構成部材の 材料定数を示す。

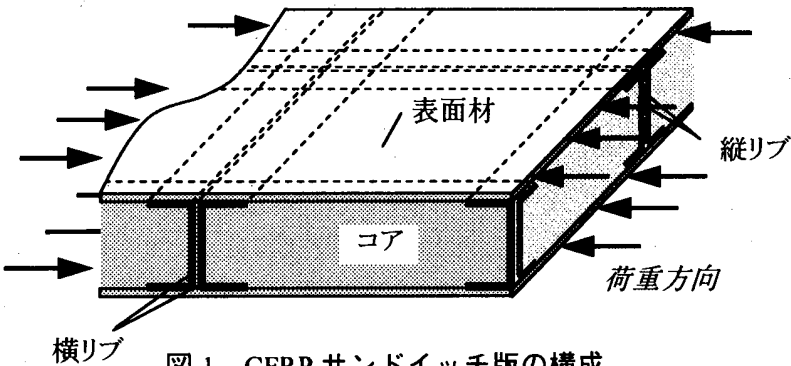

図 1 ＣFRP サンドイッチ版の構成

表 1 材料定数（L は荷重方向、Tは荷重直交方向を表わす）

\begin{tabular}{|c|c|c|c|c|c|}
\hline & \multicolumn{2}{|c|}{$\begin{array}{c}\text { ヤング係数 } \\
\mathrm{N} / \mathrm{mm}^{2}\end{array}$} & \multirow{2}{*}{$\begin{array}{c}\begin{array}{c}\text { せん断彈性 } \\
\text { 係数 } \mathrm{N} / \mathrm{mm}^{2}\end{array} \\
\mathrm{G}_{\mathrm{LT}}\end{array}$} & \multirow{2}{*}{$\frac{\text { ポアツツ比 }}{\nu}$} & \multirow{2}{*}{$\frac{\text { 比重 }}{\rho}$} \\
\hline & $\mathrm{E}_{\mathrm{L}}$ & $\overline{E_{T}}$ & & & \\
\hline 表面材 1 & 30300 & 30300 & 5390 & 0.13 & 1.85 \\
\hline 表面材 2 & 24600 & 24600 & 5490 & 0.10 & 2.20 \\
\hline リブ & 19600 & 12700 & 8160 & 0.42 & 1.92 \\
\hline ウレタン発泡体コヤ & \multicolumn{2}{|c|}{2.8} & 1.4 & 0.01 & 0.027 \\
\hline 7エ1ール発泡体つ7 & \multicolumn{2}{|c|}{6.6} & 3.3 & 0.01 & 0.064 \\
\hline
\end{tabular}

\section{3. 圧縮実験}

コアの材料にウレタン発泡体を使用し、表面材の材料に表面材 1 を使用したサンドイッチ版の圧縮実験について報告する。コアの材 料にフェノール発泡体を使用した場合については、文献 11）に示し
ているが、本研究では比較のため、それら全結果をまとめ、表 2(a) 及び表 2(b)に示すこととした。

\section{1 試験体の形状と名称}

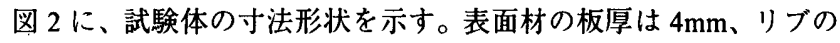
板厚は $2.2 \mathrm{~mm}$ である。試験体中央部のリブの間隔は、横リブ間隔 $a_{0}=450 \mathrm{~mm}$ 、絴リブ間隔 $b_{0}=400 \mathrm{~mm}$ である。コア厚 $75 \mathrm{~mm}$ としたも のを $\mathrm{EC}-\mathrm{U} 75$ シリーズ、コア厚 $100 \mathrm{~mm}$ としたものを $\mathrm{EC}-\mathrm{U} 100$ シリ ーズと呼ぶことにする。また、コアの材料にフェノール発泡体を使

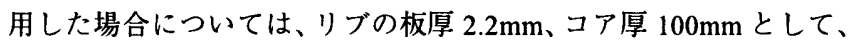

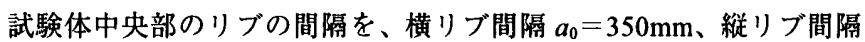
$b_{0}=450 \mathrm{~mm}$ としたものを $\mathrm{EC}-\mathrm{P} 100$ シリーズ、 $a_{0}=350 \mathrm{~mm} 、 b_{0}=225 \mathrm{~mm}$

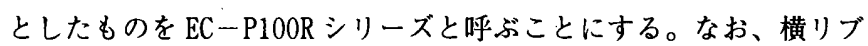
間隔 $a_{0}$ が、コア材の種類によって、 $450 \mathrm{~mm}$ と $350 \mathrm{~mm}$ の 2 種類ある のは、第 5 章の表 4(a)に示した理論座屈半波長 $a$ と $a_{0}$ の比をほほ一 定にして、荷重直交方向の拘束の影響を同様にするためである。 表 2(a)に示すように EC-U100 シリーズは 2 体、EC-U75 シリーズは 7 体、EC-P100 シリーズは 3 体、EC-P100R シリーズは 3 体の、合 計 15 体を実験した。試験体数の多いシリーズは、実験当時、実用性 が高いと判断されたもので、耐力のばらつき等のデー夕をできる限 り豊富に取ることを目的としたものである。

\section{2 実験方法}

写真 1 に示す様に6MN アムスラー型試験機で試験体に圧縮荷重 をかけた。サンドイッチ版の圧縮実験では、初期不整等があると表 莗 2 つの表面材のどちらかが先に座屈変形することが考えられるの で、図 2 に示す様に、雨表面材にひずみゲージを貼り付けた。
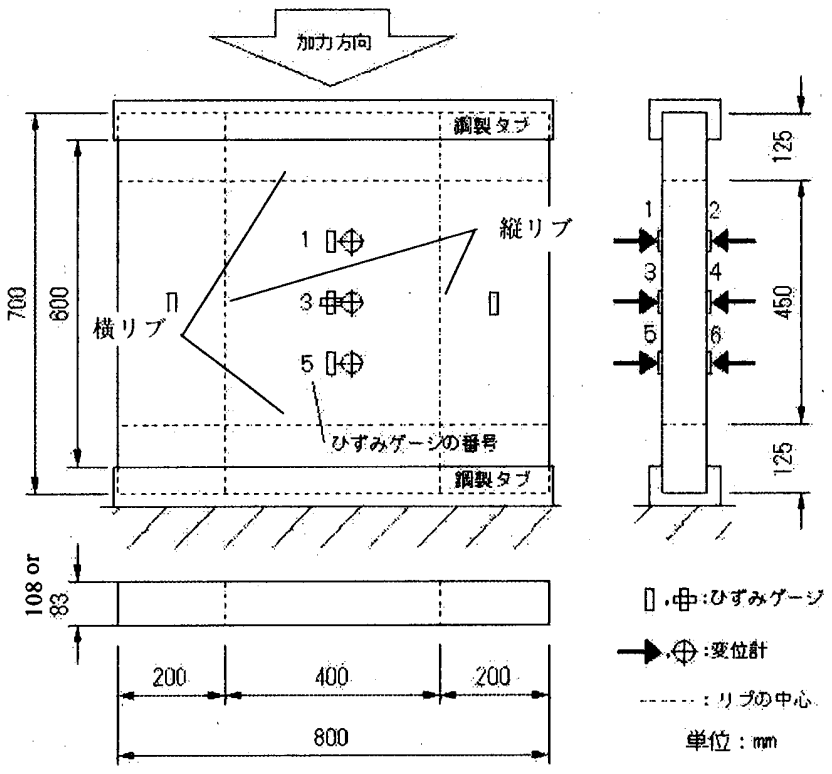

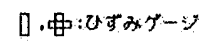

$\rightarrow \oplus$ :变位鯶 …... : ! > 単位: mm

\section{3 実験結果}

\subsection{1 荷重一ひずみ曲線}

本研究では載荷中のひずみの計測を詳細に行うことで、荷重-ひず み曲線において非線形性が顕著に表われた時点を特定し、その時点 
を局部座屈の発生とみなす文献 12)の方法を採用する。

図 3 に荷重一ひずみ曲線の例を示す。コアの材料にフェノール発 泡体を使用した場合では（図 3(b))、局部座屈荷重が生ずるとほほ 等しい荷重で最大耐力に至ったのに対し、ウレタン発泡体を使用し た場合（図 3(a)）では、局部座屈の発生以降も耐力の上昇が見られ た。

\subsection{2 座屈半波長}

写真 1 に、コアの材料にウレタン発泡体を使用した試験体の表面 材の座屈変形の一例を示す。全試験体で、表面材の局部座屈が観察 された。座屈変形の観察は、コアの材料にフェノール発泡体を使用 した場合よりも、ウレタン発泡体を使用した場合の方が比較的容易 であった。実験で探用した座屈半波長は、座屈変形を視覚的にとら えることができた状態での写真撮影から、原則として、座屈波形の 山から山の 1 波長を測り、その半分を座屈半波長 $a$ として採用した。

表 2(a)に、各試験体の座屈半波長を示す。表 2(b)に、各シリーズ の座屈半波長の平均值と標準偏差を示す。いずれも、平均值に対す る標準偏差の割合は 6〜22\%であり、写真撮影を通して得られたも のとしては、ばらつきはそれ程大きくないと言える。

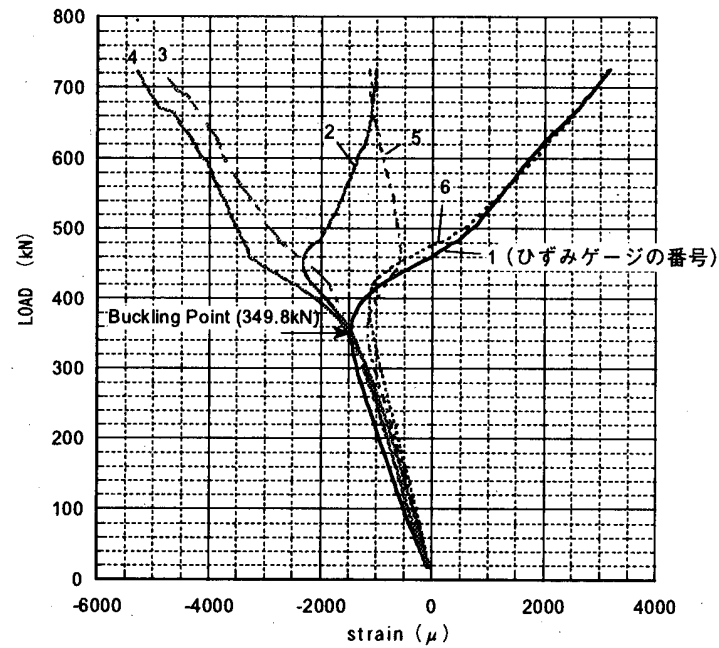

(a) ウレタン発泡体コアの場合（EC-U75-4）

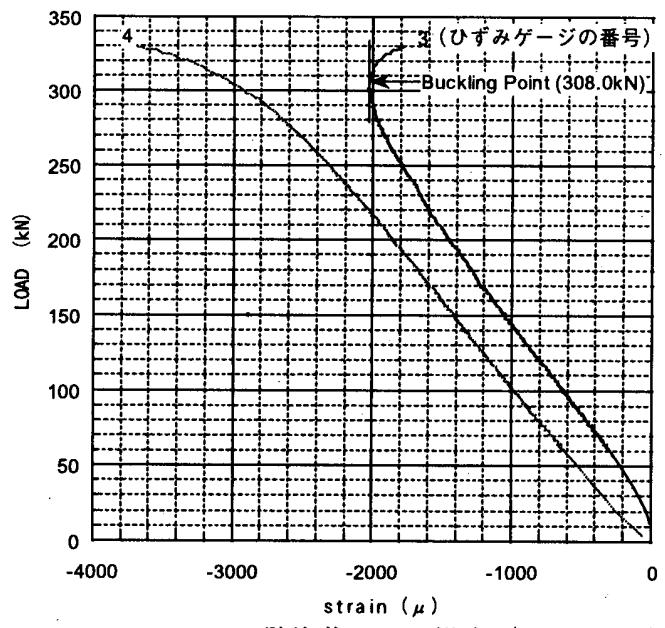

(b)フェノール発泡体コアの場合（EC-P100-1）

図 3 圧縮実験の荷重一ひずみ曲線の例

\subsection{3 局部座屈応力}

表 2(a)に、各試験体の局部座屈の発生荷重 $P_{c}$ と、局部座屈応力 $\sigma_{c}$ を示す。局部座屈応力 $\sigma_{c}$ は、 $P_{c}$ を試験体の表面材の全断面で除 した值とした。表 2(b)に、各シリーズの局部座屈応力の平均值と標 準偏差を示す。各シリーズの平均値に対する標準偏差の割合は、各 シリーズで高々 $12 \%$ 程度であり、座屈応力についても、ばらつきは 小さいと言える。

\section{4. 曲げ実験}

コアの材料にウレタン発泡体を使用し、表面材の材料に表面材.1 又は表面材 2 を使用したサンドイッチ版の曲げ実験について報告す る。コアの材料にフェノール発泡体を使用した場合については、文

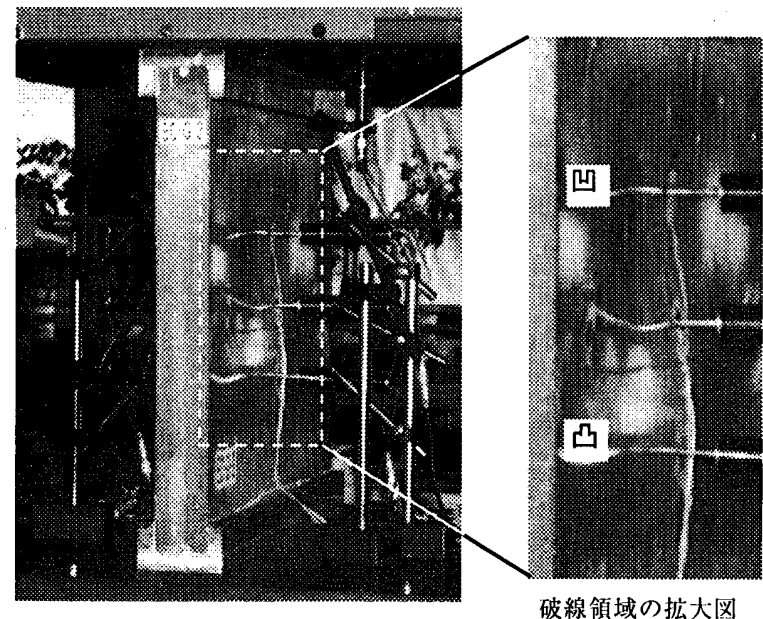

写真 1 圧縮実験の様子と表面材の局部座屈変形（EC-U75-4）

表 2(a) 圧縮実験の結果

$h_{c}$ : コア厚, $a_{0}$ : 横りブ間隔， $b_{\theta}$ : 絴リブ間觕， $A$ : 表面材の全断面皘, $P_{c}$ : 局部座属荷重, $\sigma_{\mathrm{c}}$ : 局部座屈応力, $a$ : 座屈半波長

\begin{tabular}{|l|c|c|c|c|c|c|c|}
\hline ID & $\begin{array}{c}h_{c} \\
\mathrm{~mm}\end{array}$ & $\begin{array}{c}a_{0} \\
\mathrm{~mm}\end{array}$ & $\begin{array}{c}\boldsymbol{b}_{o} \\
\mathrm{~mm}\end{array}$ & $\begin{array}{c}A \\
\mathrm{~mm}^{2}\end{array}$ & $\begin{array}{c}P_{c} \\
\mathrm{kN}\end{array}$ & $\begin{array}{c}\sigma_{c} \\
\mathrm{~N} / \mathrm{mm}^{2}\end{array}$ & $\begin{array}{c}a \\
\mathrm{~mm}\end{array}$ \\
\hline EC-U100-1 & 100 & 450 & 400 & 7160 & 417.5 & 58.3 & 140 \\
\hline EC-U100-2 & 100 & 450 & 400 & 7160 & 443.0 & 61.9 & 120 \\
\hline EC-U75-1 & 75 & 450 & 400 & 6960 & 422.5 & 60.7 & 200 \\
\hline EC-U75-2 & 75 & 450 & 400 & 6976 & 340.5 & 48.8 & 200 \\
\hline EC-U75-3 & 75 & 450 & 400 & 6972 & 323.5 & 46.4 & 160 \\
\hline EC-U75-4 & 75 & 450 & 400 & 6972 & 349.8 & 50.2 & 130 \\
\hline EC-U75-5 & 75 & 450 & 400 & 6960 & 316.1 & 45.4 & 140 \\
\hline EC-U75-6 & 75 & 450 & 400 & 6972 & 382.0 & 54.8 & 120 \\
\hline EC-U75-7 & 75 & 450 & 400 & 6976 & 344.5 & 49.4 & 140 \\
\hline EC-P100-1 & 100 & 350 & 450 & 3644 & 308.0 & 84.5 & 140 \\
\hline EC-P100-2 & 100 & 350 & 450 & 4452 & 281.5 & 63.2 & 120 \\
\hline EC-P100-3 & 100 & 350 & 450 & 4456 & 353.0 & 79.2 & 130 \\
\hline EC-P100R-1 & 100 & 350 & 225 & 4564 & 532.2 & 116.1 & 125 \\
\hline EC-P100R-2 & 100 & 350 & 225 & 4564 & 509.1 & 111.5 & 90 \\
\hline EC-P100R-3 & 100 & 350 & 225 & 4556 & 647.3 & 142.1 & 80 \\
\hline
\end{tabular}

表 2(b) 圧縮実験の結果の平均値と標準偏差

\begin{tabular}{|l|c|c|c|c|}
\hline \multirow{2}{*}{$\begin{array}{c}\text { 試験体 } \\
\text { 沙- }\end{array}$} & \multicolumn{2}{|c|}{ 局部座屈応力 } & \multicolumn{2}{|c|}{ 座屈半波長 } \\
\cline { 2 - 5 } & $\begin{array}{c}\text { 平均值 } \\
\mathrm{N} / \mathrm{mm}^{2}\end{array}$ & $\begin{array}{c}\text { 標準偏差 } \\
\mathrm{N} / \mathrm{mm}^{2}\end{array}$ & $\begin{array}{c}\text { 平均值 } \\
\mathrm{mm}\end{array}$ & $\begin{array}{c}\text { 標準偏差 } \\
\mathrm{mm}\end{array}$ \\
\hline $\mathrm{EC}-\mathrm{U} 100$ & 60.1 & - & 130 & - \\
\hline $\mathrm{EC}-U 75$ & 50.8 & $4.9(10)$ & 156 & $30(19)$ \\
\hline $\mathrm{EC}-\mathrm{P} 100$ & 75.6 & $9.1(12)$ & 130 & $8(6)$ \\
\hline $\mathrm{EC}-\mathrm{P} 100 \mathrm{R}$ & 123.4 & $13.4(11)$ & 93 & $21(22)$ \\
\hline
\end{tabular}

注：（）は、標準偏差/平均值 $\times 100 （ \%)$ を表わす。 
献 4) に示しているが、本研究では比較のため、それら全結果をま とめ、表 3(a)及び表 3(b)に示すこととした。

\section{1 試験体の形状と名称}

図 4 に、試験体の寸法形状を示す。4点曲げ実験のスパン中央付 近で、座屈を発生させるため、試験体が油圧ジャッキ先端の鋼材に 直接接する位置と試験体を支持する位置の区間では、縦りブの数量 を増やして補強した。

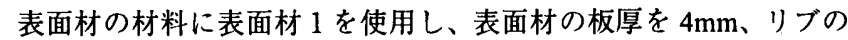
板厚を $2.2 \mathrm{~mm}$ 、試験体中央部のリブの間隔を、横りブ間隔 $a_{0}=450 \mathrm{~mm}$ 、 縦りブ間隔 $b_{0}=400 \mathrm{~mm}$ とし、コア厚 $75 \mathrm{~mm}$ としたものを EOB-U75 シリーズと呼ぶことにする。また、表面材の材料に表面材 2 を使用

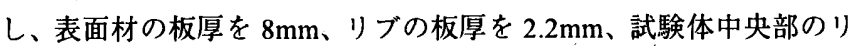
ブの間隔を、横りブ間隔 $a_{0}=400 \mathrm{~mm}$ 、縦リブ間隔 $b_{0}=400 \mathrm{~mm}$ とし、 コア厚 $200 \mathrm{~mm}$ としたものを E0B2-U200 シリーズと呼ぶことにする。 一方、コアの材料にフェノール発泡体を使用した場合については、

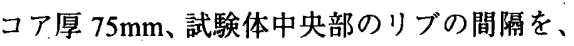
横リブ間隔 $a_{0}=450 \mathrm{~mm}$ 、縦リブ間隔 $b_{0}=$ $400 \mathrm{~mm}$ としたものを $\mathrm{EOB}-\mathrm{P} 75$ シリーズ、 $a_{0}$ $=450 \mathrm{~mm} 、 b_{0}=200 \mathrm{~mm}$ としたものを $\mathrm{EOB}-$ P75R シリーズと呼ぶことにする。表 3(a)に示 すようにEOB-U75 シリーズは.3 体、EOB2-U200 シリーズは 2 体、EOB-P75 シリーズは 9 体、 E0B-P75R シリーズは 6 体の、合計 20 体を実 験した。試験体数の多いシリーズは、現状で の実用性が高いと判断されたもので、耐力の ばらつき等のデータをできる限り豊富に取る ことを目的としたものである。

\section{2 実験方法}

写真 2 に示す様に、 4 点曲げ実験を行った。 加力は、鋼製フレームに固定された 2 つの $200 \mathrm{kN}$ 油圧ジャッキで行った。荷重值は油圧 ジャッキ先端のロードセルから読み取った。 図 4 に、ひずみゲージの貼り付け位置とその 番号を示す。

\section{3 実験結果}

\subsection{1 荷重一ひずみ曲線}

図 5 に荷重一ひずみ曲線の例を示す。曲げ 実験では、2つのジャッキを使用したので、 荷重值としては、両者の平均値を採用した。 局部座屈の発生点の定義は、圧縮実験の場合 と同様とした。圧縮実験の場合と同様、コア の材料にフェノール発泡体を使用した場合で は局部座屈荷重が生ずるとほほ等しい荷重で 最大耐力に至ったのに対し、ウレタン発泡体 を使用した場合（図 5）では局部座屈の発生 以降も酎力の上昇が見られた。

\subsection{2 座屈半波長}

写真 3 に、EOB-U75 シリーズ、EOB2-U200 シリーズの表面材の座屈 変形の例を示す。全試験体の圧縮側表面材で、局部座屈が観察され た。圧縮実験の場合と同様、座屈変形の観察は、コアの材料にフ : ノール発泡体を使用した場合よりも、ウレタン発泡体を使用した場 合の方が比較的容易であった。座屈半波長 $a$ の測定法は、圧縮害験 の場合と同様とした。

表 3(a)に、各試験体の座屈半波長を示す。コアの材料にフェノー ル発泡体を使用した場合には、座屈変形が判明しないまま終局耐力 に至る場合もあった。そうした場合では、表 3(a)中の座屈半波長 $a$ の欄に記号一で表わしている。表 3(b)に、各シリーズの座屈半波長 の平均值と標準偏差を示す。平均值に対する標準偏差は 6 ～10\%で あり、ばらつきが小さいと言える。

\subsection{3 局部座屈応力}

表 3(a)に、各試験体の局部座屈の発生荷重 $P_{c}$ と、局部座屈応力 $\sigma_{c}$
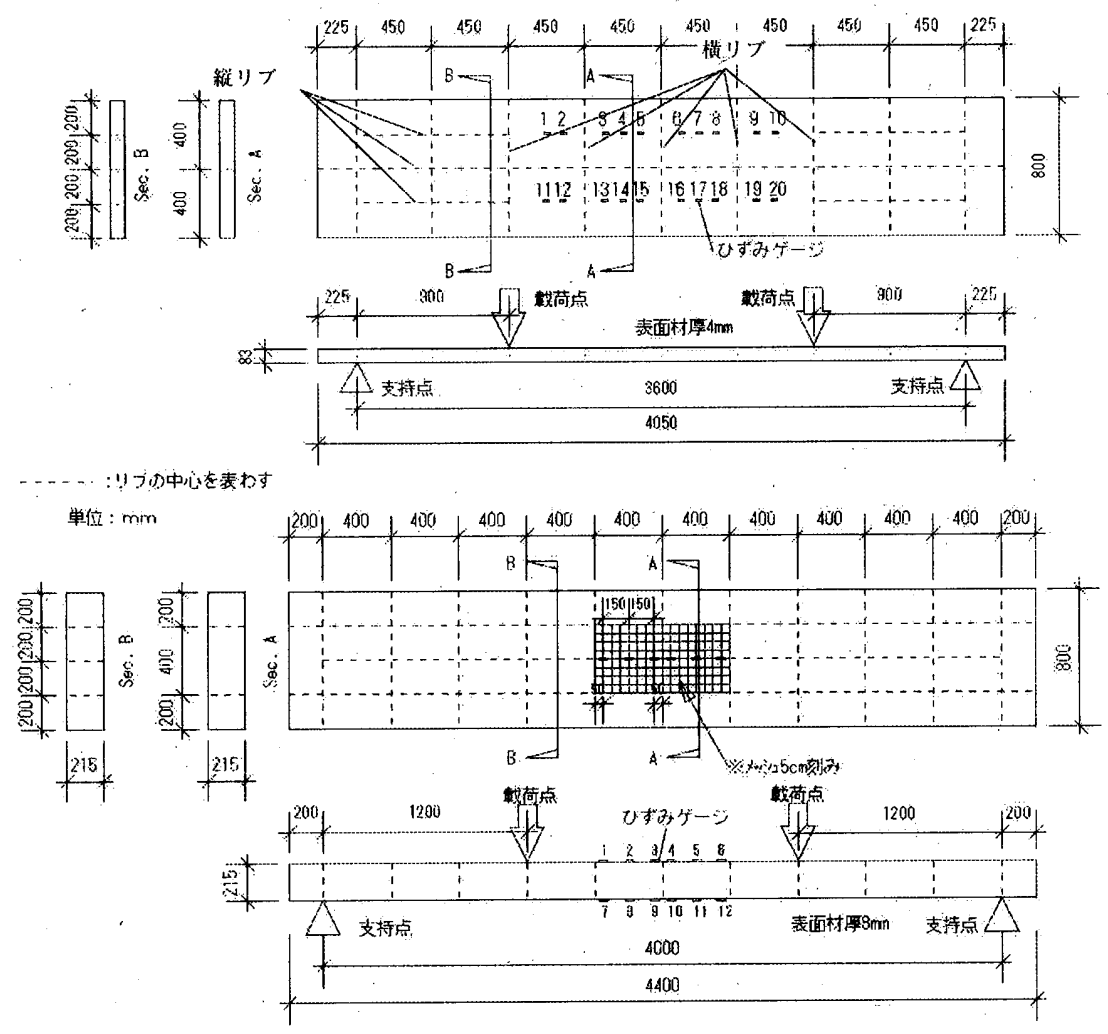

図 4 曲げ実験の試験体の形状とひずみゲージの番号

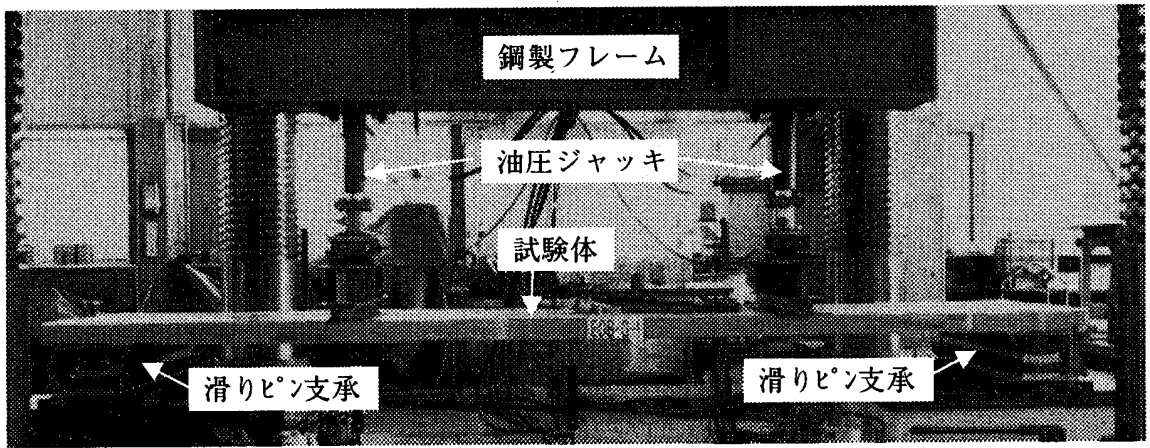

写真 2 曲げ実験（セットアップ時） 
を示す。局部座屈応力 $\sigma_{c}$ は、 $P_{c}$ を用いて次式として評価した。

$$
\sigma_{c}=P_{c} L \xi / I
$$

ここに、 $L$ は支持点から荷重点までの距離、Iはサンドイッチ版全体 の断面 2 次モーメト、そはサンドイッチ版断面の図心から最外縁まで の距離である。

表 3(b)に、各シリーズの局部座屈応力の平均值と標準偏差を示す。 平均値に対する標準偏差の割合は、高々 $10 \%$ 程度であり、ばらつき は小さいと言える。

5. Total Potential Energy（TPE）の停留原理に基づくサンドイッチ 版の理論的局部座屈応力

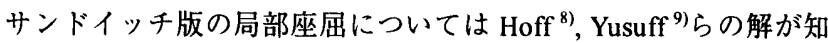
られており、文献 13 に設計式として紹介されている。しかし、荷重 方向と版厚方向の 2 次元でモデル化しているため、本研究のように 縦リブで補強されたサンドイッチ版に対しては、その効果を考慮す

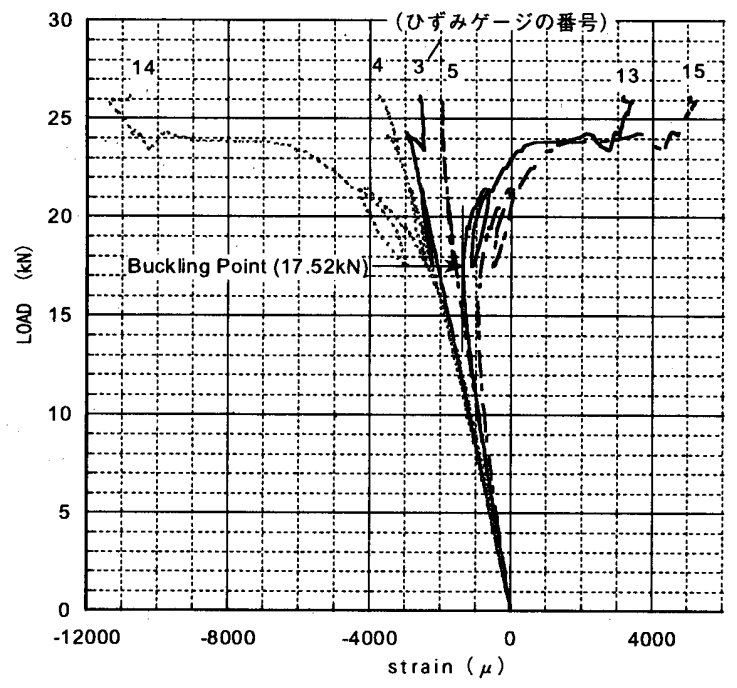

図 5 荷重一ひずみ曲線の例（EOB-U75-1）

表 3(a) 曲げ実験の結果

$h_{c}$ : コア厚， $a_{0}$ : 横リブ間隔， $b_{0}$ : 絴リブ間隔,

$B$ : 試験体の幅, $H$ : 試験体の厚さ,

$P_{c}:$ 局部座屈荷重, $\sigma_{c}$ : 局部座屈応力, $a$ : 座屈半波長

\begin{tabular}{|l|c|c|c|c|c|c|c|c|}
\hline ID & $\begin{array}{c}h_{c} \\
\mathrm{~mm}\end{array}$ & $\begin{array}{c}a_{0} \\
\mathrm{~mm}\end{array}$ & $\begin{array}{c}b_{o} \\
\mathrm{~mm}\end{array}$ & $\begin{array}{c}B \\
\mathrm{~mm}\end{array}$ & $\begin{array}{c}H \\
\mathrm{~mm}\end{array}$ & $\begin{array}{c}P_{c} \\
\mathrm{kN}\end{array}$ & $\begin{array}{c}\sigma_{c} \\
\mathrm{~N} / \mathrm{mm}^{2}\end{array}$ & $\begin{array}{c}a \\
\mathrm{~mm}\end{array}$ \\
\hline E0B-U75-1 & 75 & 450 & 400 & 832 & 84 & 17.52 & 62.1 & 125 \\
\hline EOB-U75-2 & 75 & 450 & 400 & 829 & 84 & 22.09 & 78.6 & 110 \\
\hline E0B-U75-3 & 75 & 450 & 400 & 835 & 84 & 19.50 & 68.9 & 120 \\
\hline EOB2-U200-1 & 200 & 400 & 400 & 799 & 218 & 94.03 & 78.3 & 200 \\
\hline EOB2-U200-2 & 200 & 400 & 400 & 799 & 217 & 93.71 & 78.4 & 220 \\
\hline EOB-P75-1 & 75 & 450 & 400 & 801 & 80 & 24.51 & 95.3 & 120 \\
\hline EOB-P75-2 & 75 & 450 & 400 & 795 & 81 & 20.02 & 77.3 & 150 \\
\hline EOB-P75-3 & 75 & 450 & 400 & 796 & 81 & 19.43 & 75.0 & 140 \\
\hline EOB-P75-4 & 75 & 450 & 400 & 799 & 83 & 23.97 & 89.7 & - \\
\hline EOB-P75-5 & 75 & 450 & 400 & 797 & 83 & 26.89 & 100.9 & - \\
\hline EOB-P75-6 & 75 & 450 & 400 & 811 & 83 & 22.32 & 82.3 & 120 \\
\hline EOB-P75-7 & 75 & 450 & 400 & 808 & 83 & 27.41 & 101.4 & 150 \\
\hline EOB-P75-8 & 75 & 450 & 400 & 807 & 83 & 24.77 & 91.8 & - \\
\hline EOB-P75-9 & 75 & 450 & 400 & 811 & 83 & 25.87 & 95.4 & - \\
\hline E0B-P75R-1 & 75 & 450 & 200 & 798 & 81 & 25.49 & 98.1 & - \\
\hline EOB-P75R-2 & 75 & 450 & 200 & 796 & 81 & 26.16 & 100.9 & - \\
\hline EOB-P75R-3 & 75 & 450 & 200 & 798 & 80 & 23.84 & 93.0 & - \\
\hline E0B-P75R-4 & 75 & 450 & 200 & 795 & 84 & 31.95 & 118.6 & - \\
\hline EOB-P75R-5 & 75 & 450 & 200 & 799 & 83 & 26.32 & 103.5 & - \\
\hline EOB-P75R-6 & 75 & 450 & 200 & 797 & 84 & 29.79 & 110.3 & - \\
\hline
\end{tabular}

ることができない。本研究では、Hoff, Yusuff らの方法を 3 次元に拡 張し、縦リブが存在する場合について、Total Potential Energy（以下、 TPE）の停留原理から定式化を行う。なお、本実験のケースを有限 要素法で座屈解析する場合、パラメータが非常に多いことの他、コ アのメッシュを板厚方向に何分割するかとか、コアと表面材の接合 要素をどうモデル化するかなど難しい問題がある。本研究では、事 前に、予備的解析としてのみ扱った。

\section{1 局部座屈モード}

表面材の板厚を $t 、 コ ア$ 材の厚さを $h_{c}$ 、表面材の座屈に対して、 コア材が有効に抵抗する厚さ方向の距離を $h$ とする。コア厚がある 程度大きい場合には、コアの内部には図 6 の様に、表面材の座屈変 形に無関係な領域が存在することが想定され、その時、両表面材は それぞれ独立に座屈変形が生ずる。

図 7 の様に $x 、 y 、 z$ 座標をとり、それぞれの方向の座屈（増分）

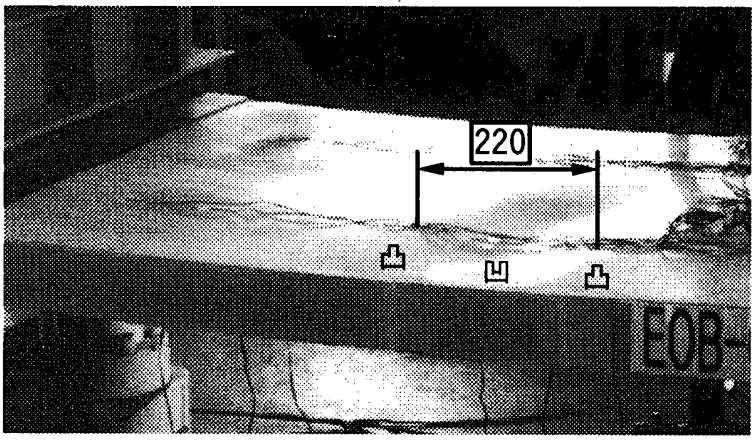

(a) E0B-U75-2（数值は, 写真から測定した座屈波長）

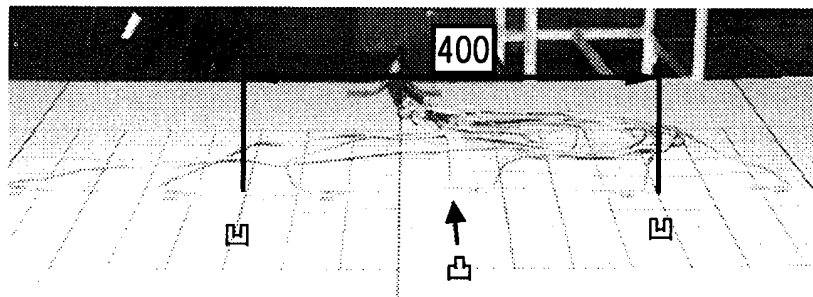

(b) E0B2-U200-1（数値は，写真から測定した座屈波長）

写真 3 曲げ荷重時の表面材の座屈変形の例（単位 mm）

表 3(b) 曲げ実験の結果の平均値と標準偏差

\begin{tabular}{|c|c|c|c|c|}
\hline & \multicolumn{2}{|c|}{ 局部座康応力 } & \multicolumn{2}{|c|}{ 來屈半波良 } \\
\hline $\begin{array}{l}\text { 試験体 } \\
\text { 沙-ス" }\end{array}$ & $\begin{array}{l}\text { 平均值 } \\
\mathrm{N} / \mathrm{mm}^{2}\end{array}$ & $\begin{array}{c}\text { 標準偏差 } \\
\mathrm{N} / \mathrm{mm}^{2}\end{array}$ & $\begin{array}{c}\text { 平均値 } \\
\mathrm{mm}\end{array}$ & $\begin{array}{c}\text { 標集偏美 } \\
\mathrm{mm}\end{array}$ \\
\hline EOB-U75 & 69.9 & $6.8(10)$ & 115 & $7(6)$ \\
\hline EOB2-U200 & 78.4 & - & 210 & - \\
\hline E0B-P75 & 89.9 & $9.2(10)$ & 136 & $14(10)$ \\
\hline E0B-P75R & 104.1 & $8.4(8)$ & - & - \\
\hline
\end{tabular}

注 1：( ) は、標準㣂差/平均做 $\times 100 （ \%)$ を表わす。

注 $2 ：$ E0B-P75 の座屈半波長については、夾屈波長が測定できた データを採用。 
変位を $(u, v, w)$ とする。局部座屈が発生する $x$ 方向、 $y$ 方向の座屈 半波長を、それぞれ $a, b$ とし、座屈モードを次式で仮定する。なお、 $w$ は表面材の中立軸における $z$ 方向の座屈変形である。この場合、 座屈波形の節となる線は、四辺単純支持の境界条件とみなすことが 出来る。

表面材部 : $u=0, v=0, \quad w=\alpha \sin \frac{\pi x}{a} \sin \frac{\pi y}{b}$

コア部 : $u_{c}=0, v_{c}=0, w_{c}=\frac{z}{h} \alpha \sin \frac{\pi x}{a} \sin \frac{\pi y}{b}$

ここで、 $\alpha$ は未定係数である。

板座屈の場合、 $u=v=0$ となるので、結果として増分線形面内ひ ずみエネルギー $U_{2 m}=0$ である。

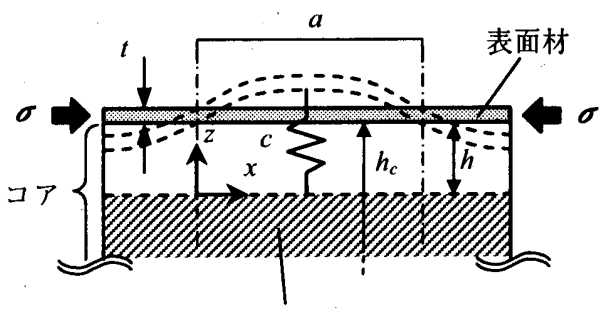

表面材の座屈変形に無関係なコアの領域

図 6 サンドイッチ版表面材の座屈

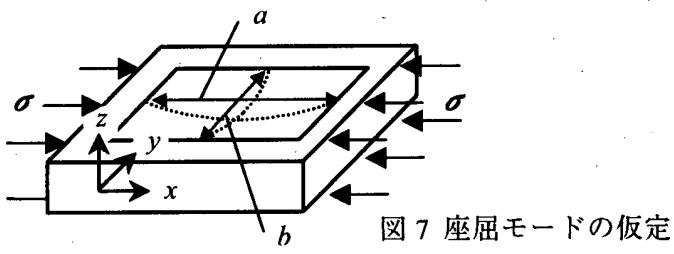

\section{2 表面材の增分曲げひずみエネルギー： $U_{2 b}$}

増分ひずみ $\left(\kappa_{x}, \kappa_{y}, \kappa_{x y}\right)$ と増分変位 $(u, v, w)$ の関係および合応 力 $\left(m_{x}, m_{y}, m_{x y}\right)$ を用いて、表面材の増分曲げひずみエネルギー $U_{2 b}$ は、次式として表わせる。

$U_{2 b}=\frac{1}{2} \int_{0}^{b} \int_{0}^{a}\left(m_{x} \kappa_{x}+m_{y} \kappa_{y}+2 m_{x y} \kappa_{x y}\right) d x d y$

ここに、

$\kappa_{x}=-\frac{\partial^{2} w}{\partial x^{2}}, \quad \kappa_{y}=-\frac{\partial^{2} w}{\partial y^{2}}, \quad \kappa_{x y}=-\frac{\partial^{2} w}{\partial x \partial y}$

$m_{x}=D\left(\kappa_{x}+v \kappa_{y}\right), m_{y}=D\left(\kappa_{y}+v \kappa_{x}\right), m_{x y}=D(1-v) \kappa_{x y}$

$D=\frac{E \cdot t^{3}}{12\left(1-v^{2}\right)}, E=$,表面材のヤング係数, $v=$ 表面材のポ予ツ比 式(4),(5)を式(3)に代入し、式(1)を用いると、

$$
\begin{aligned}
U_{2 b} & =\frac{D}{2} \int_{0}^{b} \int_{0}^{a}\left(\kappa_{x}{ }^{2}+2 v \kappa_{x} \kappa_{y}+\kappa_{y}{ }^{2}+2(1-v) \kappa_{x y}{ }^{2}\right) d x d y \\
& =\alpha^{2} \cdot \frac{D \pi^{4}}{8 a b}\left(\frac{a}{b}+\frac{b}{a}\right)^{2}
\end{aligned}
$$

\section{3 表面材の線形化された增分面内ひずみエネルギー： $V_{2 m}$}

表面材の線形化された増分面内ひずみエネルギーV $V_{2 m}$ は、增分面 内ひずみ $\left(\varepsilon_{x}, \varepsilon_{y}, \varepsilon_{x y}\right)$ の非線形項 $\left(\varepsilon_{x}{ }^{d d}, \varepsilon_{y}{ }^{d d}, \varepsilon_{x y}{ }^{d d}\right)$ 及び増
分面内合応力 $\left(n_{x}, n_{y}, n_{x y}\right)$ の非線形項 $\left(n_{x}{ }^{d d}, n_{y}{ }^{d d}, n_{x y}{ }^{d d}\right)$ と、 座屈前平衡状態のひずみ $\left(\varepsilon_{x}{ }^{F}, \varepsilon_{y}{ }^{F}, \varepsilon_{x y}{ }^{F}\right)$ や応力 $\left(n_{x}{ }^{F}, n_{y}{ }^{F}, n_{x y}{ }^{F}\right)$ を用いて次式として書ける ${ }^{14)}$ 。

$$
\begin{aligned}
V_{2 m}= & \frac{1}{2} \int_{0}^{b} \int_{0}^{a}\left(n_{x}{ }^{F} \varepsilon_{x}{ }^{d d}+n_{y}{ }^{F} \varepsilon_{y}{ }^{d d}+2 n_{x y}{ }^{F} \varepsilon_{x y}{ }^{d d}\right. \\
& \left.+n_{x}{ }^{d d} \varepsilon_{x}{ }^{F}+n_{y}{ }^{d d} \varepsilon_{y}{ }^{F}+2 n_{x y}{ }^{d d} \varepsilon_{x y}{ }^{F}\right) d x d y \\
= & \int_{0}^{b} \int_{0}^{a}\left(n_{x}{ }^{F} \varepsilon_{x}{ }^{d d}+n_{y}{ }^{F} \varepsilon_{y}{ }^{d d}+2 n_{x y}{ }^{F} \varepsilon_{x y}{ }^{d d}\right) d x d y
\end{aligned}
$$

本問題では、座屈前の平衡状態は次式としておける。

$$
n_{x}{ }^{F}=-\sigma t, n_{y}{ }^{F}=0, n_{x y}{ }^{F}=0
$$

よって、

$$
V_{2 m}=\int_{0}^{b} \int_{0}^{a}(-\sigma t) \varepsilon_{x}^{d d} d x d y
$$

$\varepsilon_{x}{ }^{d d}=\frac{1}{2}\left(\frac{\partial w}{\partial x}\right)^{2}$ を用いると、式(1)より $V_{2 m}$ は次式で表わされる。

$$
V_{2 m}=-\alpha^{2} \frac{b t \pi^{2}}{8 a} \cdot \sigma
$$

ここで、コアが無い場合 $(h=0)$ には、TPEは $\Pi \equiv U_{2 b}+V_{2 m}$ であ るので、その停留条件より、

$$
\frac{\partial \Pi}{\partial \alpha}=\alpha \cdot \frac{b \pi^{2}}{4 a} \cdot\left[\frac{D \pi^{2}}{b^{2}}\left(\frac{a}{b}+\frac{b}{a}\right)^{2}-\sigma t\right]=0
$$

上式が未定係数 $\alpha$ のいかんにかかわらず成立するときの荷重 $\sigma=\sigma_{0}$ が座屈応力であるので、コアが無い場合、即ち、四辺単純支 持の矩形板の座屈応力 $\sigma_{0}$ は、次式で表わされる。

$$
\sigma_{0}=\frac{D \pi^{2}}{t b^{2}}\left(\frac{a}{b}+\frac{b}{a}\right)^{2}
$$

\section{4 コア材についての等価ばねの導入}

コア材について、コア厚方向の単位面積当りのばね定数 $c$ を考え、 そうしたばねで、表面材が、厚さ方向に支持されている状態を考え る。このとき、表面材の座屈変位によって、コア材に蓄積する増分 ひずみエネルギーは、次式として表わされる。

$$
U_{2 c}=\frac{1}{2} \int_{0}^{b} \int_{0}^{a} c w^{2} d x d y
$$

式(1)より、

$$
U_{2 c}=\alpha^{2} \cdot \frac{a b}{8} \cdot c
$$

よって、コアを有する場合の TPE は $\Pi \equiv U_{2 b}+V_{2 m}+U_{2 c}$ であり、そ の停留条件より

$$
\frac{\partial \Pi}{\partial \alpha}=\frac{a b \alpha}{4} \cdot\left[\frac{\pi^{2}}{a^{2}}\left\{\frac{D \pi^{2}}{b^{2}}\left(\frac{a}{b}+\frac{b}{a}\right)^{2}-\sigma t\right\}+c\right]=0
$$

上式が未定係数 $\alpha$ のいかんにかかわらず成立する条件より、コア 材が存在するときの表面材の局部座屈応力は、式(11)を用いて、次 式のように表わせる。 


$$
\sigma_{c}=\sigma_{0}+\frac{a^{2}}{t \pi^{2}} \cdot c
$$

$U_{2 c}$ は、コアの $z$ 方向の垂直ひずみエネルギー成分 $U_{2 a}$ とコアの せん断ひずみエネルギー成分 $U_{2 s}$ の和で表現できるので、

$U_{2 c} \equiv U_{2 a}+U_{2 s}$

$U_{2 a}$ について、

$U_{2 a}=\frac{1}{2} \int_{0}^{h} \int_{0}^{b} \int_{0}^{a} \sigma_{z}{ }^{c} \varepsilon_{z}{ }^{c} d x d y d z=\frac{1}{2} \int_{0}^{h} \int_{0}^{b} \int_{0}^{a} E_{c}\left(\varepsilon_{z}{ }^{c}\right)^{2} d x d y d z$

ここに、 $E_{c}=$ コアのヤング係数, $\varepsilon_{z}{ }^{c}=\frac{\partial w_{c}}{\partial z}$

式(2)を用いて、 $U_{2 a}$ は、次式で表わされる。

$$
U_{2 a}=\alpha^{2} \cdot \frac{a b}{8} \cdot \frac{E_{c}}{h}
$$

$U_{2 s}$ について、

$$
\begin{aligned}
U_{2 s} & =\frac{1}{2} \int_{0}^{h} \int_{0}^{b} \int_{0}^{a}\left(2 \tau_{z x}{ }^{c} \varepsilon_{z x}{ }^{c}+2 \tau_{z y}{ }^{c} \varepsilon_{z y}{ }^{c}\right) d x d y d z \\
& =\frac{1}{2} \int_{0}^{h} \int_{0}^{b} \int_{0}^{a} 4 G_{c}\left(\left(\varepsilon_{z x}{ }^{c}\right)^{2}+\left(\varepsilon_{z y}{ }^{c}\right)^{2}\right) d x d y d z
\end{aligned}
$$

ここに、 $G_{c}=\frac{E_{c}}{2\left(1+v_{c}\right)}$ は、コアのせん断弾性係数である。

一方、式(2)を用いて、

$\varepsilon_{z x}{ }^{c}=\frac{1}{2}\left(\frac{\partial w_{c}}{\partial x}+\frac{\partial u_{c}}{\partial z}\right)=\frac{1}{2}\left(\frac{\partial w_{c}}{\partial x}\right)=\frac{1}{2} \frac{z}{h} \alpha \frac{\pi}{a} \cos \frac{\pi x}{a} \sin \frac{\pi y}{b}$

$\varepsilon_{z y}{ }^{c}=\frac{1}{2}\left(\frac{\partial w_{c}}{\partial y}+\frac{\partial u_{c}}{\partial z}\right)=\frac{1}{2}\left(\frac{\partial w_{c}}{\partial y}\right)=\frac{1}{2} \frac{z}{h} \alpha \frac{\pi}{b} \sin \frac{\pi x}{a} \cos \frac{\pi y}{b}$

であるから、 $U_{2 S}$ は、次式で表わされる。

$$
U_{2 s}=\alpha^{2} \frac{G_{c} h \pi^{2}}{24}\left(\frac{a}{b}+\frac{b}{a}\right)
$$

式(13),(16),(17)を式(15)へ代入し、cについて整理すれば、等価ば ね定数 $c$ は、次式で表わされる

$$
c=\frac{E_{c}}{h}+\frac{G_{c} h \pi^{2}}{3 a b}\left(\frac{a}{b}+\frac{b}{a}\right)
$$

ところで、式(14)から分かるように、 $\sigma_{c}$ は $c$ に関して増加関数で あるので、 $c$ が最小值をとるときが、求めるべき座屈応力である。

$\frac{d c}{d h}=0$ なる最小条件をとれば、

$$
\frac{d c}{d h}=-\frac{E_{c}}{h^{2}}+\frac{\pi^{2} G_{c}}{3 a b}\left(\frac{a}{b}+\frac{b}{a}\right)=0
$$

上式を $h$ について解くと、 $h$ は、次式で表わされる。

$$
h=\frac{1}{\pi} \sqrt{\frac{3 E_{c}}{G_{c}}} \cdot \frac{a b}{\sqrt{a^{2}+b^{2}}}
$$

式(19)を式(18)へ代入して整理すれば、

$$
c=\frac{2 \sqrt{3}}{3} \cdot \pi \sqrt{E_{c} G_{c}} \cdot \frac{\sqrt{a^{2}+b^{2}}}{a b}
$$

式(20),(11)を式(14)へ代入すれば、

$$
\sigma_{c}=\frac{D \pi^{2}}{t b^{2}}\left(\frac{a}{b}+\frac{b}{a}\right)^{2}+\frac{2 \sqrt{3}}{3 \pi} \cdot \frac{\sqrt{E_{c} G_{c}}}{t} \frac{a}{b} \sqrt{a^{2}+b^{2}}
$$

式(21)が、サンドイッチ版における一般的な場合の局部座屈応力 の解である。第 1 項は、座屈半波長 $a, b$ によって四辺が単純支持さ れたコア無し矩形板の座屈応力であり、第 2 項が、座屈半波長 $a, b$ で表わされた格子状りブ及びコア材の座屈補剛によって付加された 座屈応力分である。

なお、式(19)で得られた $h$ の值が $h_{c}$ より大きい場合には、 $U_{2 a}$ と $U_{2 s}$ の $z$ についての積分区間を $0 \sim h_{c}$ とすればよい。従って、この ときの等価ばね $c$ は、式(18)の $h$ を $h_{c}$ として次式で与えられる。

$$
c=\frac{E_{c}}{h_{c}}+\frac{G_{c} h_{c}}{3} \cdot \frac{\pi^{2}}{a b}\left(\frac{a}{b}+\frac{b}{a}\right)
$$

式(22)を式(14)へ代入すれば、

$$
\sigma_{c}=\frac{D \pi^{2}}{t b^{2}}\left(\frac{a}{b}+\frac{b}{a}\right)^{2}+\left\{\frac{E_{c}}{h_{c} t} \frac{a^{2}}{\pi^{2}}+\frac{G_{c} h_{c}}{3 t} \frac{a}{b}\left(\frac{a}{b}+\frac{b}{a}\right)\right\}
$$

\section{5 最小座屈応力と座屈半波長}

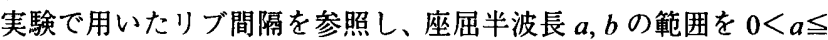
$450 、 0<b \leqq 450$ とする。予備解析から、この範囲の $a, b$ では、局部 座屈応力 $\sigma_{c}$ を表わす式(21)及び式(23)は、 $b$ に関して単調隇少関数 となる。従って、局部座屈応力 $\sigma_{c}$ の最小值を求めるには、 $b$ に最大 值 $b_{0}$ (縦リブ間隔）を採用すればよい。停留条件 $d \sigma_{c} / d a=0$ から $a$ を求め、その $a$ を用いて各式の最小值が得られる。式(23)について は、停留条件を満たす $a$ は解析的に求まり、次式で与えられる。

$$
a=\sqrt[4]{\frac{D \pi^{2}}{\frac{D \pi^{2}}{b^{4}}+\frac{E_{c}}{h_{c} \pi^{2}}+\frac{G_{c} h_{c}}{3 b^{2}}}}
$$

一方、式(21)の停留条件を満たす $a$ を解析的に求めることは難し く、数値解析的に解くことになる。結局、 $b=b_{0}$ としたとき式(21)の 停留条件は、 $a$ の 10 次方程式となる。本研究では、これを Newton-Raphson 法により解いた。なお、 $a$ の初期値には、式(24)で 得られる值を用いた。局部座屈応力の最小值（停留值）を、圧縮及 び曲げの各実験のケースについて、それぞれ表 4(a),(b)に示す。停留 点を与える $a$ が、 $h$ の条件を満たさない場合についても、参考のた め、( )付き数值で示している。

\section{6 繸リブ及びコア材の座屈補剛効果}

表 4(a),(b)に示した局部座屈応力の最小值を、Hoff ${ }^{8)}$ の座屈応力解 と比較する。縦りブの間隔が小さい場合に、本研究の理論值との差 が大きくなり、本研究で考慮した絴りブの座屈補剛効果が現われて いる。縦リブ間隔 $b_{0}$ を半分にした実験のケースでは、表 4(a)の EC -P100 と EC-P100R を比較した場合で約 $21 \%$ 、表 4(b)の E0B-P75 と EOB-P75R を比較した場合で約 $26 \%$ 座屈応力が増加することが分か る。一方、コアの材料 (弾性係数) が局部座屈応力に与える影響に ついては、表 4(b)の EOB-P75 と EOB-U75 を比較した場合、コアの材 料にフェノール発泡体を使用した場合が、ウレタン発泡体を使用し た場合に対し、座屈応力が約 64\%増加することが分かる。

$b=b_{o}$ としたときの、局部座屈応力 $\sigma_{c}$ と座屈半波長 $a$ の関係を表 した座屈応力スペクトルを、圧縮荷重の場合を図 8(a),(b),(c),(d)に、 曲げ荷重の場合を図 9(a),(b),(c),(d)に示す。このスペクトル曲線は、 $h \leqq h_{c}$ のとき式(21)を用いて、 $h_{c}<h$ のとき式(23)を用いて描かれてい 
る。コア材の無い場合、この様なスペクトル曲線は、 $a$ に対して減 少曲線となることはよく知られている。それに対し、本スペクトル 曲線は下に凸の曲線であることが注目される。即ち、座屈半波長 $a$ が、極小点をとる值より大きくなれば座屈応力が増加することを意 味している。これは式(21)及び式(23)の第二項から分かるように、コ ア材の座屈補剛効果が、 $a$ の 2 乗に比例して増加することによる。 表 4 の中で、 $\sigma_{A}$ は、式(21)及び式(23)の第二項から得られる縦リブ 及びコア材の座屈補剛によって付加された座屈応力分である。本研 究で扱った試験体の場合、コアのヤング係数は、表面材のヤング係 数の約 $10^{-4}$ 倍しかなく、構造材として荷重をほとんど負担しないが、 表面材の局部座屈に抵抗する効果については、コア無し矩形板の座 屈応力 $\sigma_{0}$ と同等以上の極めて大きな座屈補剛効果を有しているこ とが分かる。

\section{6. 理論と実験の比較}

表 5 は、局部座屈応力についての実験の平均値と理論最小値を比 較したものである。実験の平均値と理論最小值はほほ一致している と言える。E0B-U75 では、実験值は理論最小值に対し、やや高い值 をとっている。これは実験後の試験体断面の調査で、試験体側面部 のリブが、製造過程で肉厚となっていたことが判明し、そのために、 境界条件が半剛接的に作用したものと考えられる。

図 8、図 9 に実験結果をプロットし、理論曲線（座屈応力スペク トル）と比較する。実験結果は、黒丸でプロットした。なお、フェ ノール発泡体コア材を使用した曲げ実験で、座屈半波長が測定でき なかった試験体については、理論的に最小座屈応力を与える座屈半 波長を用いて、記号×でプロットした。各シリーズにおいて、理論 曲線と実験結果はよく一致していると言える。

表 5 局部座屈応力の実験値と理論最小值の比較

\begin{tabular}{|c|c|c|c|c|}
\hline $\begin{array}{l}\text { 試験体 } \\
\text { 沙- } \boldsymbol{X}^{*}\end{array}$ & コア材 & $\begin{array}{c}\text { 実験平均値 } \\
\mathrm{N} / \mathrm{mm}^{2}\end{array}$ & $\begin{array}{c}\text { 理論最小值 } \\
\mathrm{N} / \mathrm{mm}^{2}\end{array}$ & $\begin{array}{l}\text { 実験 } \\
\text { /理論 }\end{array}$ \\
\hline EC-U100 & タータ & 60.1 & 51.8 & 1.16 \\
\hline EC-U75 & カレタン & 50.8 & 53.7 & 0.95 \\
\hline EC-P100 & $7 x /-1$ & 75.6 & 85.6 & 0.88 \\
\hline EC-P100R & $7 x /-1$ & 123.4 & 104.0 & 1.19 \\
\hline EOB-U75 & 斿 & 69.9 & 53.7 & 1.30 \\
\hline EOB2-U200 & 辛タン & 78.4 & 73.5 & 1.07 \\
\hline EOB-P75 & $7 x /-1$ & 89.9 & 87.8 & 1.02 \\
\hline EOB-P75R & $7 x /-1$ & 104.1 & 110.6 & 0.94 \\
\hline
\end{tabular}

\section{7. 結論}

本研究では、減圧吸引成形法で製造された格子状りブを有する CFRP サンドイッチ版について圧縮及び曲げ実験を行い、表面材の 局部座屈について、座屈応力及び座屈半波長を計測した。さらに、 Total Potential Energy の停留原理から、表面材の局部座屈応力に関し、 陽な形での定式化を行い、縦リブ及びコア材の座屈補剛効果を理論 的に明らかにした。座屈応力と座屈半波長の関係を示す理論曲線(座 屈応力スペクトル）と実験結果はよく一致し、本式の有効性を確か めることができた。

\section{謝辞}

本研究を進めるにあたり、試験体、物性デー夕の提供など東レ(侏) LSS 開発推進グループの近藤敏行氏、松浦正史氏、安倍一峰氏には、
表 4 局部座屈応力の停留点の值

$h_{c}$ : コア厚 $(\mathrm{mm}), b_{0}:$ 縦リブ間隔 $(\mathrm{mm}), t:$ 表面材の板厚 $(\mathrm{mm})$,

$a:$ 座屈半波長 $(\mathrm{mm})$

$h$ : 座屈の影響を受けるコア厚 $(\mathrm{mm})$, $\sigma_{0}$ : 四辺単純支持矩形板の座屈応力 $\left(N / \mathrm{mm}^{2}\right)$, $\sigma_{A}:$ リブ及びコア材の座屈抵抗応力 $\left(N / \mathrm{mm}^{2}\right)$, $\sigma_{c}:$ サンドイッチ版の局部座屈応力 $\left(N / \mathrm{mm}^{2}\right)$

(a) 圧縮実験のシリーズ

\begin{tabular}{|c|c|c|c|c|c|}
\hline \multicolumn{2}{|c|}{ 試験体シリーズ } & $\begin{array}{l}\text { EC- } \\
\text { U100 }\end{array}$ & $\begin{array}{l}\mathrm{EC}- \\
\mathrm{U} 75\end{array}$ & $\begin{array}{l}\mathrm{EC}- \\
\mathrm{P} 100\end{array}$ & $\begin{array}{c}\text { EC- } \\
\text { P100R }\end{array}$ \\
\hline \multicolumn{2}{|c|}{ コアの材料 } & \multicolumn{2}{|c|}{ ウレタン発泡体 } & \multicolumn{2}{|c|}{ フェノール発泡体 } \\
\hline \multicolumn{2}{|c|}{ 表面材の材料 } & 表面材 I & 表面材 1 & 表面材 1 & 表面材 1 \\
\hline \multicolumn{2}{|c|}{$t$} & 4 & 4 & 4 & 4 \\
\hline \multicolumn{2}{|c|}{$b_{a}$} & 400 & 400 & 450 & 225 \\
\hline \multicolumn{2}{|c|}{$h_{c}$} & 100 & 75 & 100 & 100 \\
\hline \multirow{3}{*}{$\begin{array}{c}\text { 式(2l)の }) \\
\text { 倍留俌 }\end{array}$} & $a(N R$ 法) & 155 & 155 & 120 & 110 \\
\hline & $h\left(x^{(}(19)\right)$ & 117.0 & 117.0 & 90.1 & 77.2 \\
\hline & $\sigma_{0}$ & $(22.3)$ & $(22.3)$ & 32.6 & 51.3 \\
\hline \multirow[t]{2}{*}{$h \leqq h_{c}$} & $\sigma_{A}$ & $(29.2)$ & $(29.2)$ & 53.0 & 52.7 \\
\hline & $\sigma_{c}(\mathbf{C}(21))$ & $(51.5)$ & (51.5) & 85.6 & 104.0 \\
\hline \multirow{3}{*}{$\begin{array}{c}\text { 式(23)の }) \\
\text { 停留值 }\end{array}$} & $a($ 式(24)) & 150 & 141 & 122 & 114 \\
\hline & $h($ 式(19)) & 113.9 & 107.9 & 92.0 & 79.5 \\
\hline & $\sigma_{0}$ & 23.4 & 25.6 & $(31.3)$ & $(49.1)$ \\
\hline \multirow[t]{2}{*}{$h_{c}<h$} & $\sigma_{A}$ & 28.4 & 28.1 & (54.5) & $(56.5)$ \\
\hline & $\sigma_{c}(\bar{I}(23))$ & 51.8 & 53.7 & $(\mathbf{8 5 . 8})$ & (105.6) \\
\hline \multirow{3}{*}{ Hoff $^{8)}$} & $h$ & 134.3 & 134.3 & \multicolumn{2}{|c|}{96.0} \\
\hline & $a$ & 166 & 166 & \multicolumn{2}{|c|}{123} \\
\hline & $\sigma_{c}$ & 47.6 & 55.0 & \multicolumn{2}{|c|}{73.1} \\
\hline
\end{tabular}

(b) 曲げ実験のシリーズ

\begin{tabular}{|c|c|c|c|c|c|}
\hline \multicolumn{2}{|c|}{ 試験体沙- $\mathbf{R}^{*}$} & $\begin{array}{l}\text { EOB- } \\
\text { U75 }\end{array}$ & $\begin{array}{l}\text { EOB2- } \\
\text { U200 }\end{array}$ & $\begin{array}{l}\text { E0B- } \\
\text { P75 }\end{array}$ & $\begin{array}{l}\text { EOB- } \\
\text { P75R }\end{array}$ \\
\hline \multicolumn{2}{|c|}{ コアの材料 } & \multicolumn{2}{|c|}{ ウレタン発泡体 } & \multicolumn{2}{|c|}{ フェノール発泡体 } \\
\hline \multicolumn{2}{|c|}{ 表面材の材料 } & $\begin{array}{l}\text { 表面材 } 1 \\
\end{array}$ & 表面材 2 & 表䫄材 1 & 表面材 1 \\
\hline \multicolumn{2}{|c|}{$t$} & 4 & 8 & 4 & 4 \\
\hline \multicolumn{2}{|c|}{$b_{0}$} & 400 & 400 & 400 & 200 \\
\hline \multicolumn{2}{|c|}{$h_{c}$} & 75 & 200 & 75 & 75 \\
\hline \multirow{3}{*}{$\begin{array}{c}\text { 式(21)の } \\
\text { 停留值 }\end{array}$} & $a(N R$ 法) & 155 & 274 & 119 & 108 \\
\hline & $h($ 式(19)) & 117.0 & 183.1 & 88.6 & 73.9 \\
\hline & $\sigma_{0}$ & (22.3) & 47.6 & $(34.2)$ & 58.2 \\
\hline \multirow[t]{2}{*}{$h \leqq h_{c}$} & $\sigma_{A}$ & $(29.2)$ & 25.9 & $(53.0)$ & 52.4 \\
\hline & $\sigma_{c}($ 式(2I)) & $(51.5)$ & 73.5 & $(87.2)$ & 110.6 \\
\hline \multirow{3}{*}{$\begin{array}{c}\text { 武(23)の } \\
\text { 倍留倠 }\end{array}$} & $a\left(\mathrm{C}^{\prime}(24)\right)$ & 141 & 277 & 114 & 108 \\
\hline & $h(-1(19))$ & 107.9 & 184.1 & 85.7 & 74.0 \\
\hline & $\sigma_{0}$ & 25.6 & $(47.3)$ & 36.3 & $(58.1)$ \\
\hline \multirow[t]{2}{*}{$h_{c}<h$} & $\overline{\sigma_{A}}$ & 28.1 & $(26.3)$ & 51.5 & (52.5) \\
\hline & $\sigma_{c}\left(x^{\prime}(23)\right)$ & 53.7 & (73.6) & 87.8 & (110.6) \\
\hline \multirow{3}{*}{$\operatorname{Hoff}^{8)}$} & $h$ & 134.3 & 281.9 & \multicolumn{2}{|c|}{96.0} \\
\hline & $a$ & 166 & 348 & \multicolumn{2}{|c|}{123} \\
\hline & $\sigma_{c}$ & 55.0 & 45.5 & \multicolumn{2}{|c|}{84.4} \\
\hline
\end{tabular}

泣) NR 法：Newton-Raphson 法

多大なご協力を頂きました。また、実験に際し、清水建設(株技術研 究所の杉崎健一博士、藤崎忠志氏、兼光知巳博士、米丸啓介博士に は、適切な助言を頂きました。ここに、感謝の意を表わします。 


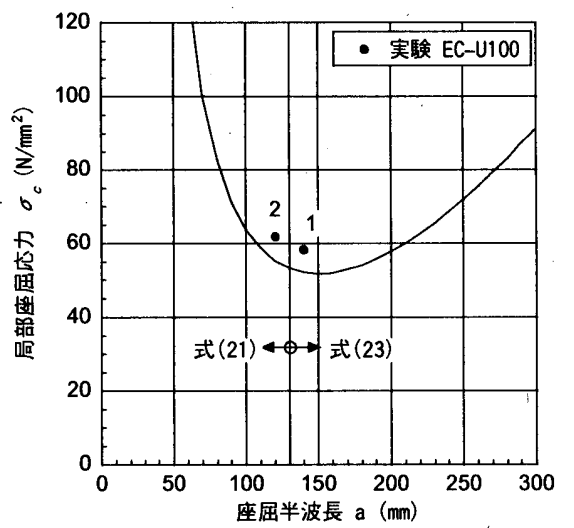

図 8(a) 圧縮実験と理論曲線の比較 (EC-U100)

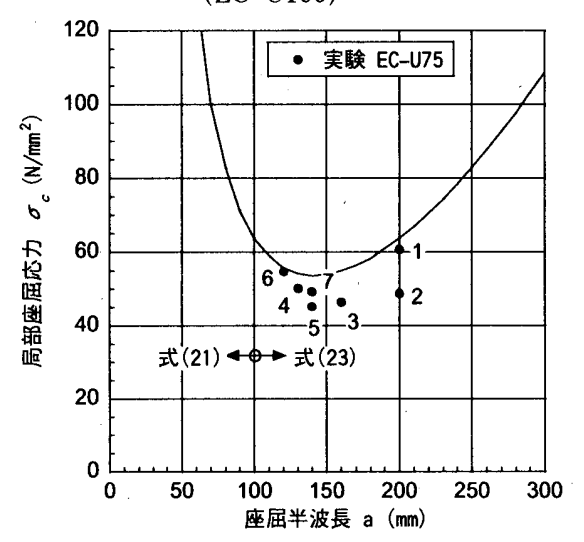

図 8(b) 圧縮実験と理論曲線の比較 (EC-U75)

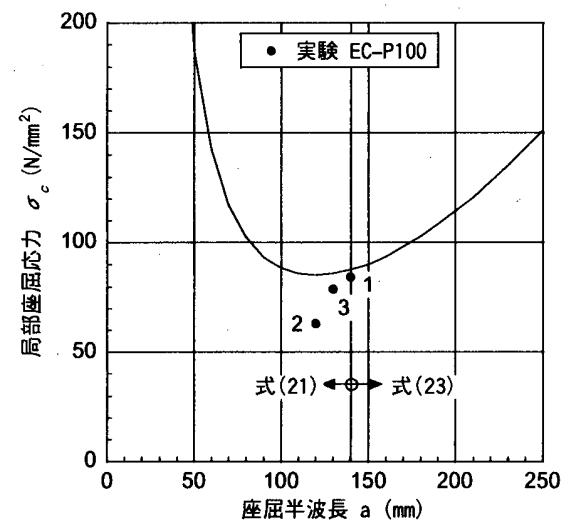

図 8(c) 圧縮実験と理論曲線の比較 (EC-P100)

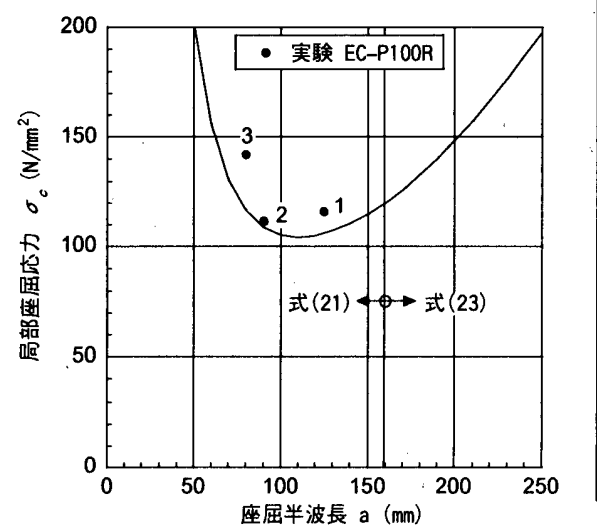

図 8(d) 圧縮実験と理論曲線の比較 (EC-P100R)

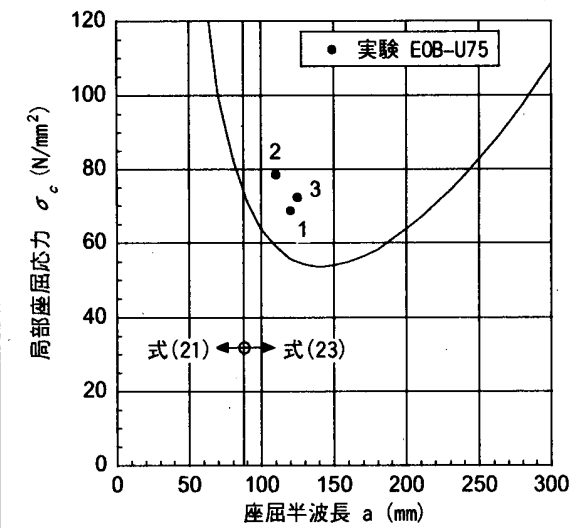

図 9(a) 曲げ実験と理論曲線の比較 (EOB-U75)

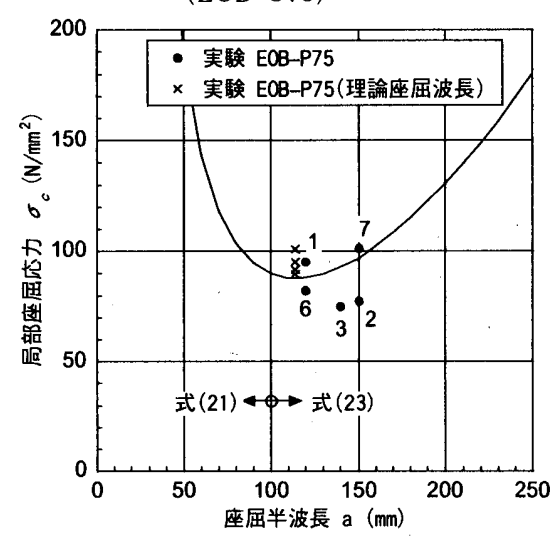

図 9(c) 曲げ実験と理論曲線の比較 (EOB-P75)

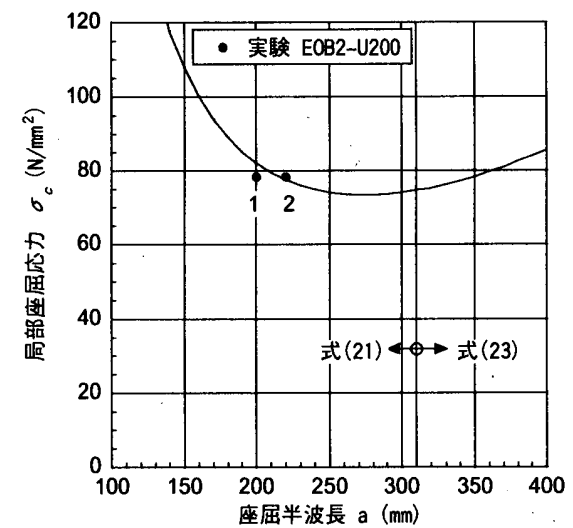

図 9(b) 曲げ実験と理論曲線の比較 (EOB2-U200)

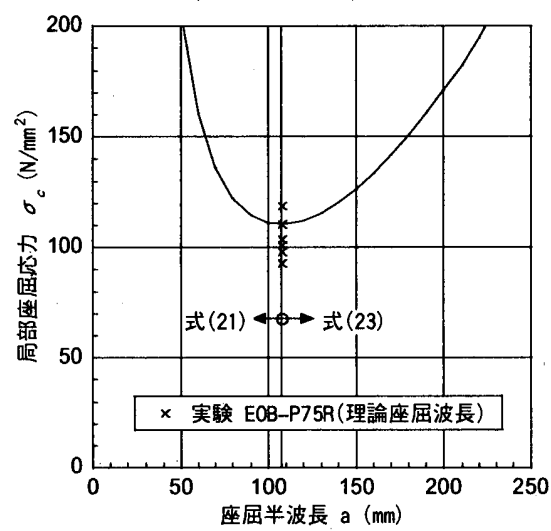

図 9(d) 曲げ実験と理論曲線の比較 (EOB-P75R)

\section{参考文献}

1）FRP 用途事例集，(社）強化プラスチック協会，2000.10

2) Advanced Materials, Structural Engineering International, IABSE, Vol.12, No.2, 2002

3) Hiroshi Fukuyama : FRP Composites in Japan, Concrete International, Oct.1999

4）立石寧俊, 杉崎健一, 藤崎忠志, 兼光知已, 米丸繁介, 近藤敏行：CFRP サ ンドイッチ版屋根の開発，日本建築学会技術報告集，第 14 号, pp133-138, 2001.12

5）後藤卒土民：「レジントランスファー成形法（RTM 法）その1 RTM 法 とは」, 強化ブラスチックス, Vol.46, No.3, pp.26〜137, 2000.9.

6）金原勲：講座 FRP 構造の力学（その5）重ねはり・サドイッチはり，強化プ ラスチックス, Vol.19, №.11, 1973

7）金原勲：講座 FRP 構造の力学（その 10）柱及び平板の座丮，強化ブラス チックス, Vol.20, №.9, 1974

8) N. J. Hoff and S. E. Mautner : The Buckling of Sandwich-Type Panels, Journal of the Institute of Aeronautical Sciences, Vol.12, No.3, pp285-297, July 1945

9) S.Yusuff: "Theory of Wrinkling in Sandwich Construction", Jour. of the Royal Aeronautical Society, Vol.59, January, 1955, pp.30-36

10）原口忠次郎：弾性基碟上の矩形板，山海堂，1964

11）立石寧俊, 杉崎健一, 兼光知已：CFRPモノコックパネルの開発, 清水建 設研究報告, Vol.71, pp41-51, 2000.4

12) F.J. Plantema : Sandwich Construction, John Wiley \& Sons, pp155-161, 1966

13) 林毅編：複合材料工学, 日科技速, 1971

14）日本機栈学会編：シェルの振動と座屚ハンドブック，pp29-37, 2003.1 